\title{
Detection of Bovine Coronavirus in Feces by Reversed Passive Hemagglutination
}

\author{
$\mathrm{By}$ \\ K. Sato ${ }^{1}, \mathrm{Y} . \mathrm{Inaba}^{1}, \mathrm{~S}$. Tokuhisa ${ }^{1}, \mathrm{Y} . \mathrm{Miura}^{1}$, \\ N. Kaneko ${ }^{1}$, M. Asagi ${ }^{2}$, and M. Matunoto ${ }^{3}$ \\ 1 National Institute of Animal Health, Tsukuba, Ibaraki, Japan \\ 2 ZEN-NOH Institute of Animal Health, Sakura, Chiba, Japan \\ 3 Kitasato Institute, Minato-ku, Tokyo, Japan \\ Accepted October 6, 1983
}

\begin{abstract}
Summary
A reversed passive hemagglutination (RPHA) method was developed for the detection of bovine coronavirus in fecal specimens. Sheep erythrocytes fixed with glutaraldehyde, and then treated with tannic acid were coated with anti-bovine coronavirus rabbit antibodies purified by affinity chromatography using bovine coronavirus linked to Sepharose $4 \mathrm{~B}$. The RPHA test was carried out by a microtiter method. Erythrocytes coated with purified specific antibodies were agglutinated by bovine coronavirus, but not by bovine rotavirus or enterovirus. The reaction was inhibited by antiserum to bovine coronavirus, confirming the specificity of the reaction. The RPHA test detected bovine coronavirus in 13 of 22 fecal specimens (59 per cent), from natural cases of diarrhea, while the positive rates were only 14 per cent $(3 / 22)$ and 22 per cent $(5 / 22)$ for immunofluorescent staining of primary cultures of calf kidney cells infected with the specimens, and immune electron microscopy respectively. The advantages of the RPHA method are its simplicity, high sensitivity and rapidity.
\end{abstract}

\section{Introduction}

Mebus and his associates $(9,11,17)$ have demonstrated an agent with the morphologic features of a coronavirus by electron microscopy of the feces of calves with neonatal diarrhea, and have proved it to be a causative agent of the disease. The virus multiplied in bovine embryonic kidney cell cultures, but failed to induce a readily recognizable cytopathic effect. Therefore although the virus may be assayed in these cultures, the method 
is rather cumbersome, as the presence of virus is detected either by the microscopic examination of stained cultures, or by immunofluorescence with a specific antiserum (10). INABA et al. (7) have demonstrated that the virus replicates readily producing a marked cytopathic effect in cultures of the continuous cell lines. BEK-1, derived from bovine embryonic kidney, thus providing a sensitive, practical assay method for the virus and neutralizing antibody. A hemagglutination-inhibition test was also developed $(14,16)$. More recently TAKAHASH et al. (18) have isolated a bovine coronavirus strain from feces in an outbreak of diarrhea among adult cows in primary cultures of calf kidney cells. However a cytopathic effect was not detected until the 8th blind passage. The demonstration of the virus in diarrheal feces by virus isolation and electron microscopy is therefore time consuming and the procedures are elaborate.

SaIEKata et al. $(12,13)$ have reported that the reversed passive hemagglutination (RPHA) test is a useful and practical method for the detection of rotavirus in the feces of infants with acute gastroenteritis. The advantages of the RPHA method are its simplicity, high sensitivity compared with the electron microscopy, and its rapidity.

These observations prompted us to investigate the application of RPHA to the detection of bovine coronavirus in the feces of cattle with diarrhea.

\section{Materials and Methods}

\section{Cell Cultures}

Primary bovine kidney (BK) cells were grown at $37^{\circ} \mathrm{C}$ in Eagle's minimum essential medium (MEM) containing 10 per cent tryptose phosphate broth (TPB) (Difco), 10 per cent calf serum, $100 \mathrm{units} / \mathrm{ml}$ penicillin, $100 \mu \mathrm{g} / \mathrm{ml}$ streptomycin and $1 \mu \mathrm{g} / \mathrm{ml}$ fungizone. The maintenance medium was MEM containing 10 per cent TPB. 0.05 per cent yeast extract, 0.5 per cent sodium glutamate, 0.1 per cent glucose and antibiotics.

\section{Viruses}

The Kakegawa strain of bovine coronavirus (18) was used. This strain was isolated in our laboratory from a cow with diarrhea and is identical to the bovine coronavirus of MEBUS et al. (10) by neutralization and immunofluorescence. The Shimane strain of bovine rotavirus (15) and the BFI strain of bovine enterovirus (6) were also used. Both were propagated in BK cells.

\section{Infectivity Assay}

This was carried out in BK cell cultures prepared in $11 \times 100 \mathrm{~mm}$ tubes. Serial 10 -fold dilutions of the virus-containing material were made in maintenance medium, and each dilution was inoculated $(0.1 \mathrm{ml} /$ tube) into 3 tube cultures. The inoculated cultures were incubated in a roller drum apparatus at $37^{\circ} \mathrm{C}$ for 5 days and were examined for any cytopathic effect. The 50 per cent infectious dose (TCID 50 ) of virus was calculated.

\section{Virus Purification}

Bovine coronavirus was purified from the culture fluid of BK cells infected with the Kakegawa strain which had been passaged eleven times in BK cells. Infectious 
culture fluid, clarified by centrifugation at $5,000 \times g$ for 30 minutes was centrifuged at $100,000 \times g$ for 2 hours. The deposit was resuspended in 0.005 volumes of PBS $(0.15 \mathrm{M} \mathrm{NaCl}, 0.01 \mathrm{~m}$ phosphate buffer, $\mathrm{pH} 7.2)$ and centrifuged at $5,000 \times g$ for 30 minutes. The supernatant fluid from this centrifugation was mixed with a $\mathrm{CsCl}$ solution to a density of $1.224 \mathrm{~g} / \mathrm{ml}$ and centrifuged in a Beckman SW 50.1 rotor at $100,000 \times g$ for 18 hours. The gradient was collected in $0.3 \mathrm{ml}$ volumes and fractions with a buoyant density of 1.235 to 1.250 were pooled, and dialyzed against PBS at $4^{\circ} \mathrm{C}$ for 18 hours. The resulting material was layered on to a $10-60$ per cent sucrose density gradient and centrifuged in a Beckman. SW 25 rotor at $100,000 \times g$ for 2 hours. Fractions $(0.3 \mathrm{ml})$ were collected and those containing $10 \mu \mathrm{g} / \mathrm{ml}$ or more protein as determined by optical density were pooled and dialyzed against PBS at $4^{\circ} \mathrm{C}$ for 62 hours. The resulting virus suspension was tested for infectivity, and for protein content by the method of LowRY et al. (8).

Rotavirus and enterovirus were concentrated by centrifugation of infectious culture fluid at $100,000 \times g$ for 2 hours. After resuspension in 0.01 volume of PBS the purified virus was clarified by centrifugation at $5000 \times g$ for 30 minutes.

\section{Antisera}

Antisera against the Kakegawa strain was prepared in rabbits. Virus grown in BK cell cultures was purified up to the step of $\mathrm{CsCl}$ density gradient centrifugation as described above. Fractions with a buoyant density of 1.235 to $1.250 \mathrm{~g} / \mathrm{ml}$ were pooled and dialyzed at $4^{\circ} \mathrm{C}$ for 18 hours against PBS. Sufficient PBS was added to the resulting material to make a suspension concentrated 100 -fold from the original culture fluid.

Each rabbit received one intravenous dose of $1 \mathrm{ml}$ of virus suspension, followed after 2 weeks by an intramuscular dose of $2 \mathrm{ml}$ of equal volumes of virus suspension and Freund's complete adjuvant. A further intramuscular dose was given at 4 weeks, and serum was obtained 2 weeks later. The antiserum used in the present study had a neutralizing antibody titer of 1:4096, and a hemagglutination-inhibiting antibody titer of $1: 2560$.

\section{Affinity Chromatography of Antiserum}

Specific antibodies to the Kakegawa strain were purified by affinity chromatography from a rabbit antiserum using CNBr-activated Sepharose $4 \mathrm{~B}$ coupled to bovine coronavirus, purified as described above. The method was essentially that of Axín et al. (1) and CUatredasas et al. (3). Three grammes of Sepharose 4B (Pharmacia Fine Chemicals, Sweden) activated by $\mathrm{CNBr}$ was added to $8 \mathrm{ml}$ of diluent $(0.5 \mathrm{M}$ $\mathrm{NaCl}, 0.1 \mathrm{M} \mathrm{NaHCO}$ ) containing $50 \mu \mathrm{g} / \mathrm{ml}$ of purified virus protein. The mixture was stirred at room temperature for 2 hours, mixed with $10 \mathrm{ml}$ of $0.2 \mathrm{M}$ glycine, $\mathrm{pH} 8.0$ (Wako Chemicals, Japan) and stirred for one additional hour. This material was packed into a $9-\mathrm{mm}$ diameter column and washed repeatedly with a solution containing $0.5 \mathrm{M} \mathrm{NaCl}$ and $0.1 \mathrm{M} \mathrm{NaHCO}_{3}$ until the $\mathrm{pH}$ of the eluate was 8.3. The column was further washed with $0.5 \mathrm{M} \mathrm{NaCl}$ in $0.1 \mathrm{~m}$ acetic acid, $\mathrm{pH} 4.0$ (until the $\mathrm{pH}$ of the filtrate became 4.0) and then equilibrated with PBS. The column was stored at $4^{\circ} \mathrm{C}$ after filling with 0.2 per cent $\mathrm{NaN}_{2}$.

For the purification of specific antibodies, rabbit antiserum against the Kakegawa strain was inactivated at $56^{\circ} \mathrm{C}$ for 30 minutes and centrifuged at $27,000 \times g$ for 30 minutes. Eight $\mathrm{ml}$ of the supernatant fluid was applied to the column, which was then washed with PBS until buffer passing through had an optical density of zero. Specific antibody to bovine coronavirus was eluted with $3 \mathrm{M}$ sodium thiocyanate solution in $0.3 \mathrm{ml}$ fractions, which were tested for optical density. Fractions containing $10 \mu \mathrm{g} / \mathrm{ml}$ or more of protein were pooled and dialyzed against PBS at $4^{\circ} \mathrm{C}$ for 18 hours. 


\section{Coating of Erythrocytes with Purified Antibodies}

Sheep blood was collected in Alsever's solution. After 5 washes with PBS the erythrocytes were fixed by mixing equal volumes of a 10 per cent suspension and 1 per cent glutaraldehyde (Iwai Chemicals, Japan) in PBS. The mixture was incubated at room temperature for 20 hours with occasional shaking. The fixed cells were washed 4 times with PBS, suspended in PBS at a concentration of 10 per cent and mixed with an equal volume of $50 \mu \mathrm{g} / \mathrm{ml}$ tannic acid (Merck, West Germany) in PBS. After incubation at $37^{\circ} \mathrm{C}$ for 15 minutes the cells were washed 5 times with PBS, suspended in PBS at a concentration of 10 per cent and mixed with an equal volume of PBS containing specific antibodies to bovine coronavirus purified as described above. After incubation at room temperature for 1 hour, the cells were washed twice and a 1 per cent suspension was prepared. The diluent used for washing and preparation of the suspension was PBS containing 2 per cent calf serum and 0.2 per cent $\mathrm{NaN}_{2}$. The calf serum used was shown to be free of antibodies to bovine coronavirus and was absorbed with glutaraldehyde-fixed erythrocytes at $37^{\circ} \mathrm{C}$ for 1 hour to remove antibodies to sheep red blood cells.

\section{RPHA Test}

The test was carried out by a microtiter method, using the diluent described above. In microplates of $V$ type (Linbro., U.S.A.), serial twofold dilutions of the test sample were made in $25 \mu \mathrm{l}$ volumes, mixed with $25 \mu \mathrm{l}$ of a 1 per cent suspension of sheep erythrocytes coated with purified antibodies to bovine coronavirus, and allowed to stand at room temperature for 1 hour. The RPHA titer was expressed as the reciprocal of the highest dilution of the sample showing hemagglutination.

One gramme of each fecal specimen to be tested was homogenized in $5 \mathrm{ml}$ of PBS and the homogenate was centrifuged at $5,000 \times g$ for 30 minutes. The supernatant fluid was absorbed at $37^{\circ} \mathrm{C}$ for 30 minutes with glutaraldehyde-fixed sheep erythrocytes.

\section{RPHA Inhibition Test}

Serum for the test was absorbed at $37^{\circ} \mathrm{C}$ for 30 minutes with glutaraldehyde-fixed sheep erythrocytes. Both the serum dilution method and the virus dilution method were used. In the latter method, undiluted and serial twofold dilutions of virus suspension in $25 \mu \mathrm{l}$ volumes were mixed with equal volumes of 10 -fold diluted antiserum against bovine coronavirus. The mixtures were incubated for 1 hour at $37^{\circ} \mathrm{C}$ after which $25 \mu \mathrm{l}$ of a suspension of erythrocytes coated with bovine coronavirus antibodies were added. After incubation at room temperature for 1 hour, the pattern of hemagghutination was observed. In the serum dilution method, serial twofold dilutions of serum were mixed with an equal volumes of diluent containing 4 RPHA units of virus, and processed as described above. The inhibition titer of the serum was expressed as the reciprocal of the highest dilution showing complete RPHA inhibition.

\section{Immunofluorescent (IF) Staining}

This was carried out by the indirect method using rabbit antiserum against the Kakegawa strain. Infected BK cells in tube cultures were incubated at $37^{\circ} \mathrm{C}$ for 2 days in a roller drum apparatus and then scraped of the glass using a rubber policeman. The cells, suspended in PBS, were smeared onto glass slides, air-dried and fixed in acetone at $-20^{\circ} \mathrm{C}$ for 30 minutes. The fixed preparations were treated at $37^{\circ} \mathrm{C}$ for 40 minutes with specific rabbit antiserum, stained at $37^{\circ} \mathrm{C}$ for 40 minutes with fluorescein isothiocyanate-conjugated goat antibody to rabbit IgG (Miles, U.S.A.) and examined for fluorescence. 


\section{Electron Microscopy}

A 20 per cent suspension of feces in PBS was centrifuged at $5,000 \times g$ for 30 minutes and the supernatant was filtered through $\approx$ membrane filter with a pore size of $450 \mathrm{~nm}$. One $\mathrm{ml}$ of the filtrate was mixed with $4 \mathrm{ml}$ of a 1:10 dilution in PBS of the rabbit antiserum against bovine coronavirus and incubated at $4^{\circ} \mathrm{C}$ for 18 hours. This material was centrifuged at $100,000 \times g$ for 2 hours, and the pellets resuspended in $0.1 \mathrm{ml}$ of PBS were examined by the negative staining technique with phosphotungstate in a Jeol JEM-100 Cx electron microscope (Jeol Ltd., Japan).

\section{Hemagglutination-Inhibition (HI) Test}

This was carried out by a microtiter method using chicken erythrocytes (14). Serum to be tested was inactivated at $56^{\circ} \mathrm{C}$ for 30 minutes and then treated with kaolin and packed chicken erythrocytes. The serum-antigen mixtures were incubated at room temperature for 1 hour, then mixed with chicken erythrocyte suspension and incubated at room temperature for a further hour. The HI titer was expressed as the reciprocal of the highest serum dilution showing complete inhibition of hemagglutination by $4 \mathrm{HA}$ units.

\section{Results}

Sheep erythrocytes were fixed with glutaraldehyde, treated with tannic acid and coated with various amounts of purified antibodies to bovine coronavirus. Using these erythrocytes the RPHA titer was determined for a concentrated suspension of purified bovine coronavirus with a titer of $10^{8.2}$ TCID $_{50} / 0.1 \mathrm{ml}$. The results are summarized in Table 1. Erythrocytes treated with antibody concentrations from 1 to $60 \mu \mathrm{g} / \mathrm{ml}$ gave an RPHA titer of $1: 64$ whereas those treated with 70 to $100 \mu \mathrm{g} / \mathrm{ml}$ antibody gave an RPHA titer of 1:128. Coated erythrocytes did not agglutinate in the absence of the virus, and virus did not agglutinate erythrocytes fixed with glutaraldehyde or fixed erythrocytes and treated with tannic acid. Based. on these results erythrocytes coated with $80 \mu \mathrm{g} / \mathrm{ml}$ of the purified antibodies were used in the following experiments. A concentrated suspension of bovine rotavirus with a titer of $10^{8.2} \operatorname{TCID}_{50} / 0.1 \mathrm{ml}$ and a similar suspension of bovine enterovirus with a titer of $10^{9.2}$ TCID $_{50} / 0.1 \mathrm{ml}$ gave negative results in the RPHA test providing further confirmation of the specificity of the test. The fecal specimen from which the Kakegawa strain of bovine coronavirus was isolated (18), gave an RPHA titer of $1: 16$. In the virus dilution method of RPHA inhibition, a 10-fold dilution of the rabbit antiserum against bovine coronavirus completely inhibited hemagglutination produced by the concentrated suspension of bovine coronavirus as well as that due to the fecal specimen which yielded the Kakegawa strain. The pre-immunization serum as well as antisera against bovine rotavirus and enterovirus did not inhibit the RPHA reaction. In the serum dilution method of RPHA inhibition the antiserum had a titer of 1:512.

RPHA tests were carried out on fecal specimens from cattle with diarrhea. Of the 22 specimens tested, 12 were collected from calves, 0.5 to 
Table 1. Effect on RPHA titer of the amount of purified antibody used for coating of sheep exythrocytes fixed with glutaraldehyde and treated with tannic acid

Amount of antibody for coating

RPHA titer ${ }^{a}$

\begin{tabular}{rr}
\hline $0 \mu \mathrm{g} / \mathrm{ml}$ & $<2$ \\
$1 \mu \mathrm{g} / \mathrm{ml}$ & 64 \\
$5 \mu \mathrm{g} / \mathrm{ml}$ & 64 \\
$10 \sim 60 \mu \mathrm{g} / \mathrm{ml}$ & 64 \\
$70 \sim 100 \mu \mathrm{g} / \mathrm{ml}$ & 128 \\
\hline
\end{tabular}

a RPHA titer of a purified coronavirus suspension with $10^{8.2}$ TCID $50 / 0.1 \mathrm{ml}$ and $2000 \mu \mathrm{g} / \mathrm{ml}$ protein, using erythrocytes coated with indicated amount of purified. antibody

1 month of age during an outbreak of acute gastroenteritis in the Fukushima Prefecture in March 1982. The remaining 10 specimens were obtained during an outbreak of diarrhea among milking cows in the Miyagi Prefecture in April 1982. All the specimens were also tested by immune electron microscopy and immunofluorescence. Acute and convalescent serum samples were available from 15 of the 22 animals and these were tested for HI antibody against the Kakegawa strain. The results are summarized in Table 2. In RPHA tests 12 of the 22 fecal specimens, or 59 per cent, were positive and the remaining 9 were negative $(</: 2)$. The positive specimens did not agglutinate erythrocytes fixed with glutaraldehyde or fixed erythrocytes treated with tannic acid. Of the 13 positives, 3 had titers equal to or higher than $1: 8,2$ had a titer of $1: 4$ and the remaining 8 had a low titer of $1: 2$. The fecal specimens from calves had a higher positive rate $(10 / 12$, 83 per cent) than those from milking cows $(3 / 10,30$ per cent). In the virus dilution method of RPHA inhibition a 10 fold dilution of the rabbit antiserum against bovine coronavirus inhibited the reaction of the positive specimens, whereas no inhibition was shown with the pre-immunization serum.

RPHA tests were carried out on 12 fecal specimens from healthy cattle. The specimens gave invariably negative results, supporting the specificity of the test.

Serum from 15 of the 22 animals were tested for HI antibody against the Kakegawa strain, and significant rises in titer were demonstrated in 10 of these ( 67 per cent). The remaining 5 animals had HI antibodies, but showed no rise in titer. Of the fecal specimens from the 10 animals showing a rise in HI titer, 7 were positive in RPHA tests and 3 were negative, whereas of the fecal specimens from the remaining 5 animals which did not have rises in titer, only one was positive in RPHA tests. However, the difference in the positive rate of RPHA reaction observed between the two groups was not statistically significant (Fisher's exact test). By the IF staining method only 3 specimens, or 14 per cent, were positive, while 
Table 2. HI tests of serum and RPHA test, IF staining and electron microscopy (EM) for detection of bovine coronavirus from diarrheal fecal specimens

\begin{tabular}{|c|c|c|c|c|c|}
\hline \multirow[b]{2}{*}{ Fecal specimen } & \multicolumn{2}{|c|}{ HI titer } & \multirow{2}{*}{$\begin{array}{l}\text { RPHA } \\
\text { titer }\end{array}$} & \multirow[b]{2}{*}{ IF staining } & \multirow[b]{2}{*}{ FMI } \\
\hline & Acute & Conv. & & & \\
\hline \multicolumn{6}{|l|}{ Calves } \\
\hline 1 & $n t^{a}$ & nt & $<2$ & - & - \\
\hline 2 & nt & $\mathrm{nt}$ & $<2$ & - & - \\
\hline 3 & nt & nt & 2 & - & - \\
\hline 4 & 20 & 640 & 2 & - & - \\
\hline 5 & nt & nt & $\geq 8$ & + & + \\
\hline 6 & 20 & 640 & 2 & - & - \\
\hline 7 & nt & $n t$ & $\geq 8$ & + & + \\
\hline 8 & 80 & 40 & 2 & -- & - \\
\hline 9 & nt & at & 2 & - & - \\
\hline 10 & $\mathrm{nt}$ & nt & 2 & - & - \\
\hline 11 & $<10$ & 160 & $\geq 8$ & + & + \\
\hline 12 & $<10$ & 160 & 4 & - & + \\
\hline \multicolumn{6}{|l|}{ Milking cows } \\
\hline 13 & 10 & 160 & $<2$ & - & - \\
\hline 14 & 80 & 80 & $<2$ & - & - \\
\hline 15 & 40 & 80 & $<2$ & - & - \\
\hline 16 & 80 & 640 & $<2$ & - & - \\
\hline 17 & 40 & 160 & $<2$ & - & - \\
\hline 18 & 40 & 40 & $<2$ & - & -- \\
\hline 19 & 160 & 80 & $<2$ & - & - \\
\hline 20 & 10 & 320 & 4 & - & + \\
\hline 21 & 10 & 320 & 2 & - & + \\
\hline 22 & 10 & 160 & 2 & - & - \\
\hline Positive rate & $10 / 15^{b}$ & $(67 \%)$ & $13 / 22(59 \%)$ & $3 / 22(14 \%)$ & $6 / 22(27 \%)$ \\
\hline
\end{tabular}

a nt: not tested

b (The number of animals with titer rise)/(The number of animals tested)

electron microscopy gave a positive rate of $6 / 22$ or 27 per cent. The specimens positive by the IF staining method were also positive in the RPHA test and the electron microscopy. All the specimens positive by electron microscopy were also positive in the RPHA test. This observation, that the positive rate obtained by RPHA test was higher than those by the other methods, was not statistically significant.

\section{Diseussion}

In the present study the RPHA method was shown to be useful and practical for the detection of bovine coronavirus in the feces of cattle with acute gastroenteritis, although the number of fecal specimens examined in the present study was small. Bovine coronavirus has been demonstrated in 
fecal specimens by the immunofluorescent staining of cell cultures inoculated with the specimen $(2,10,18)$, and by electron microscopy $(4,5,11$, 17, 18). However, these methods are time consuming and elaborate procedures. On the other hand, the RPHA method is simple and the results are obtained in a short time.

The RPHA method developed in this study was shown to be specific for bovine coronavirus. The RPHA reaction occurred only with bovine coronavirus, not with bovine rotavirus or enterovirus, and the reaction was inhibited by antiserum against bovine coronavirus, whereas no inhibition could be demonstrated with pre-immunization sera or antisera against bovine rotavirus and enterovirus. Furthermore the fecal specimen which yielded the Kakegawa strain of bovine coronavirus (18), had a RPHA titer of $1: 16$ and the reaction was specifically inhibited by antiserum against the virus. Bovine coronavirus was detected by RPHA more frequently in the feces of those cattle which had a rise in $\mathrm{HI}$ antibody to the virus than of those which did not. This observation provides further evidence of the specificity of RPHA test. However, the observed difference was not statistically significant, and further confirmation of this finding is required. The concentration of purified specific antibodies to bovine coronavirus used for the coating of erythrocytes was important in obtaining a high sensitivity for the test. The rate of detection of bovine coronavirus in the fecal specimen from natural cases was higher ( 59 per cent) by the RPHA method than by the IF staining technique (14 per cent) or electron microscopy (27 per cent). However, these results require further confirmation as the differences observed were not statistically significant. The RPHA test could find wide application in the study of bovine coronavirus infections in cattle. RPHA may also be applicable to other viral infections such rotavirus infection of cattle and transmissible gastroenteritis of swine, in which virus is excreted in abundance in the feces.

\section{References}

1. Axén, R., Forath, J., ERnBack, S.: Chemical Coupling of peptides and proteins to polysaccharides by means of cyanogen halides. Nature (Lond.) 214, 1302-1304 (1967).

2. Bridger, J. C., Woode, G. N., Meyling, A.: Isolation of coronaviruses from neonatal calf diarrhea in Great Britain and Denmark. Vet. Microbiol. 3, 101-113 (1978).

3. Cuatrecasas, P., Wilchek, M., Anfinsen, C. B.: Selective enzyme purification by affinity chromatography. Proc. Natl. Acad. Sci. U.S.A. 61, 636-643 (1968).

4. Durham, P. J. K., Stevenson, B. J., Farquharson, B. C.: Rotavirus and coronavirus associated diarrhea in domestic animals. N. Z. Vet. J. 27, 30-32 (1979).

5. Horner, G. W., Hunter, R., Kirkbride, C. A. : A coronavirus-like agent present in feces of cows with diarrhea. N. Z. Vet. J. 23, 98 (1976).

6. Inaba, Y., Omori, T., Kono, M., IshiI, S., Matumoto, M.: BFl virus: a new cytopathogenic virus isolated from cattle. I. Isolation and properties. Jpn. J. Exp. Med. 32, 77-92 (1962). 
7. Inaba, Y., Sato, K., Kurogi, H., Takahashi, E., Ito, Y., Omori, T., Goto, Y., Matumoto, M.: Replication of bovine coronavirus in cell line BEK-1 culture. Arch. Virol. 50, 339-342 (1976).

8. Lowry, O. H., Rosebrough, N. J., Farr, A. L., Randall, R. J.: Protein measurement with the Folin phenol reagent. J. Biol. Chem. 193, 265-275 (1951).

9. Mebus, C. A., White, R. G., Statr, E. L., Rhodes, M. B., Twiehaus, M. J.: Neonatal calf diarrhea: results of a field trial using a reovirus-like virus vaccine. Vet. Med. Small Anim. Clin. 67, 173-178 (1972).

10. Mebus, C. A., Stair, E. L., Rhodes, M. B., Twiehaus, M. J.: Neonatal calf diarrhea: propagation, attenuation and characteristics of a coronavirus-like agent. Am. J. Vet. Res. 34, 145-150 (1973).

11. Mebus, C. A., Stair, E. L., Twiehaus, M. J.: Pathology of neonatal calf diarrhea induced by a coronavirus-like agent. Vet. Pathol. 10, 45-64 (1973).

12. Sanekata, T., Yoshida, Y., Oda, K.: Detection of rotavirus from feces by reversed passive haemagglutination method. J. Clin. Pathol. 32, 963 (1979).

13. Sanekata, T., Yosmida, Y., Saito, Y., Takei, T., Takahashi, T.: Detection of rotavirus from infantile gastroenteritis patient's stools by means of reversed passive haemagglutination. Igaku no Ayumi 109, 319-321 (1979). (In Japanese.)

14. Sato, K., Inaba, Y., Kurogr, H., Takahashi, E., Satoda, K., Omort, T., Matuмото, M.: Hemagglutination by ealf diarrhea coronavirus. Vet. Microbiol. 2, $83-87$ (1977).

15. Sato, K., Inaba, Y., Takahashi, E., Ito, Y., Kurogi, H., Akashi, H., Satoda, K., OmoRI, T., Matumoto, M.: Isolation of a reovirus-like agent (rotavirus) from neonatal calf diarrhea in Japan. Microbiol. Immunol. 22, $499-503$ (1978).

16. Sharpee, R. L., Mebus, C. A., Bass, E. P.: Characterization of a calf diarrheal coronavirus. Am. J. Vet. Res. 37, 1031-1041 (1976).

17. Statr, E. L., Rhodes, M. B., White, R. G., Mebus, C. A.: Neonatal calf diarrhea: purification and electron microscopy of a coronavirus-like agent. Amer. J. Vet. Res. 33, 1147--1156 (1972).

18. Takahashi, E., Inaba, Y., Sato, K., Ito, Y., Kurogi, H., Akashi, H., Satoda, K., OMORI, T.: Epizootic diarrhea of adult cattle associated with a coronavirus-like agent. Vet. Microbiol. 5, 151-154 (1980).

Authors' address: Dr. Y. InABA, National Institute of Animal Health, Tsukuba, Ibaraki, 305, Japan.

Received June 27, 1983 